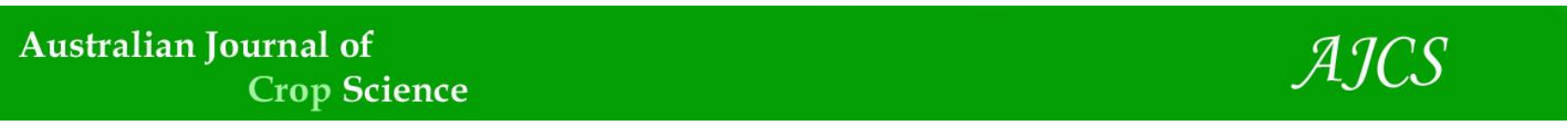

AJCS 15(10):1364-1371 (2021)

ISSN:1835-2707

doi: 10.21475/ajcs.21.15.10.p3379

\title{
Sustainable weed management in a lettuce growing conservationist system
}

\author{
Andreia Cristina Silva Hirata ${ }^{1 *}$, Patrícia Andrea Monquero², Edson Kiyoharu Hirata ${ }^{3}$ \\ ${ }^{1}$ Agency for Agribusiness Technology of São Paulo - APTA, Presidente Prudente, São Paulo State, Brazil \\ ${ }^{2}$ Department of Natural Resources and Environmental Protection, São Carlos University, Araras, São Paulo State, \\ Brazil \\ ${ }^{3}$ Sato-Hirata Seedlings, Presidente Prudente, São Paulo State, Brazil
}

*Corresponding author: andreia.hirata@sp.gov.br

\begin{abstract}
Soil disturbance, irrigation, and nitrogen fertilization excesses in lettuce crops have reduced the sustainability of the sector and favoured competition against weeds. This study aimed to evaluate the effect of cover crops and nitrogen fertilization management on weed control, weed-species dynamics, and soil seed bank in successive lettuce cultivation under no-tillage. The experiment was carried out in a tropical region during summer and arranged in a $(3 \times 4)+1$ factorial scheme. Treatments consisted of three soil cover managements (Crotalaria juncea, Urochloa ruziziensis, and fallow) and four nitrogen $(\mathrm{N})$ topdressing rates $(0,60,120$, and 180 kg $\mathrm{ha}^{-1}$ ) in a lettuce crop under fertigation. A conventional tillage system under more intense soil disturbance was also evaluated at the highest $\mathrm{N}$ rate. The results showed that lettuce cultivation on $U$. ruziziensis stood out regarding weed control. Higher soil disturbance in the conventional tillage increased weed emergence ( 288.9 and 245.8 plants $\mathrm{m}^{-2}$ ) compared to the fallow area (13.9 and 38.9 plants $\left.\mathrm{m}^{-2}\right), U$. ruziziensis $\left(4.2\right.$ and 9.7 plants $\left.\mathrm{m}^{-2}\right)$, and C. juncea $\left(56.9\right.$ and 20.8 plants $\mathrm{m}^{-2}$ ) in successive cultivations, respectively. Soil cover management changed the dynamics of weed species emergence, especially in the first cultivation. Nitrogen topdressings did not affect weed dry matter and density at the time of weeding. The average number of non-dormant weed seeds within the 0.0-0.10 m soil seed bank layer reached 7,077 seeds $\mathrm{m}^{-2}$, with no difference among treatments. Therefore, sustainable management of lettuce cultivation using cover crops in rotation, associated with no-tillage, effectively controls weed communities, with emphasis on $U$. ruziziensis, regardless of the nitrogen fertilization management.
\end{abstract}

Keywords: Crotalaria juncea, fallow, Lactuca sativa, no-tillage, Urochloa ruziziensis, weed seed bank.

\section{Introduction}

Conservation agriculture has been promoted as a method to increase sustainability and mitigate climate change, and globally used and implemented (Lundy et al., 2015; Pittelkow et al., 2015). In this conservationist context, cover crops produce biomass that can contribute to soil and water conservation, as well as increase soil nitrogen and organic matter, and suppress weed infestation (Creamer and Baldwin, 2000; Isık et al., 2009; Mennan et al., 2020).

Currently, weed management is based on herbicide application and soil tillage. However, both measures have promoted growing negative environmental impacts and weed resistance (MacLaren et al., 2020).

Production system changes may alter weed population dynamics and management (Ngouajio et al., 2003, Buhler, 1997). Given the scarcity of herbicides for "minor crops", high labour cost and limitations, viable cultural practices are needed to control weeds in leafy vegetables such as lettuce (Shem-Tov et al., 2006). In this sense, studies on lettuce have shown that cover crop effects on weeds are species-specific (Isık et al., 2009, Hirata et al., 2014).

Nitrogen supply is another key factor in integrated weed management, and its levels can affect weed interference with crops (Jørnsgård et al., 1996, Abouziena et al., 2007, Wang et al., 2019). Therefore, nitrogen fertilization level can enhance crop competitiveness against weeds (Evans et al.,
2003; Wang et al., 2019), but so can the opposite (Andreasen et al., 2006). This is because some weed species respond better than crops to nitrogen inputs and may therefore be more competitive at higher rates. According to Jørnsgård et al. (1996), increases in nitrogen rates tend to decrease total weed biomass and have a differential effect on individual species biomass. Therefore, the effects of nitrogen levels on crops and weeds must be well understood (Barker et al., 2006).

Tillage practices can also change physical and chemical soil properties, leading to changes in seed banks (Nicolik et al., 2020, Murphy et al., 2006). Added to this, larval foraging of weed-seed predators is known to be up to 10 times more intense in no-tillage than in conventional tillage areas (Blubaugh and Kaplan, 2015).

Mennan et al. (2020) emphasized that cover crops are rarely used in growing vegetables in several regions. This scenario is due to technological gaps and a lack of experimentation at a local scale. To this end, Kruse and Nair (2016) suggested that cover crops can be integrated into vegetable cultivation, but species selection is a critical factor for success.

Given the above, this study aimed to evaluate the effect of cover crops and nitrogen fertilization on weed control, weed-species dynamics, and soil seed bank in successive lettuce cultivation under no-tillage. 


\section{Results and discussion}

Soil cover and nitrogen fertilization showed independent effects on weeds, with no interaction between them for weed density and dry matter.

\section{Soil cover}

In the first cultivation, weed density was markedly reduced under Urochloa ruziziensis cover (Figure 1). Fallow and Crotalaria juncea cover areas did not differ from each other. $U$. ruziziensis cover was about 10 times more efficient in controlling weed emergence than was $C$. juncea. The initial amounts of $C$. juncea and $U$. ruziziensis straw were 5.3 and $4.4 \mathrm{t} \mathrm{ha}^{-1}$, reaching 3.0 and $2.2 \mathrm{t} \mathrm{ha}^{-1}$ at the end of the experiment, respectively. Therefore, there was little difference between the initial amounts of straw of both cover crops. $U$. ruziziensis cover controlled weeds successfully due to a dense straw layer formation and homogeneous soil cover. By contrast, $C$. juncea did not fully cover the soil owning to a greater stem volume and rapid leaf decomposition. This is because legumes generally have high nitrogen content in plant matter and produce low C:N ratio straw, hence relatively fast decomposition (Silva et al. 2009). Grasses, in turn, have large amounts of biomass high $\mathrm{C} / \mathrm{N}$, increasing soil cover persistence. Finally, the fallow area was kept free of weeds during cover crop growth, explaining its similar weed control efficiency as $C$. juncea cover.

Weed biomass was expressively reduced under Urochloa ruziziensis cover as did weed density. Similarly, Kruse and Nair (2016) found lower weed biomass in lettuce cultivation under cover of Avena strigosa, Sorghum bicolor, and Fagopyrum esculentum straw compared to conventional tillage. Isik et al. (2009) found that Vicia villosa, Sorghum bicolor, and $S$. vulgare covers reduced total dry weed biomass in lettuce crops by $90.3,87.4$, and $86.9 \%$, respectively.

Soil cover managements did not differ from each other in the second consecutive lettuce crop. This is because the absence of soil disturbance prevented the emergence of new plants. According to Jensen (1995), weed emergence increases after soil tillage are due to seed exposure to light. In this sense, Buhler (1997) pointed out that seeds of many plant species require brief exposure to light to induce germination. Therefore, changes in the light availability during soil tillage may alter weed emergence.

Regarding species, in the first cultivation, C. juncea and fallow managements showed a higher proportion of Cyperaceae and lower of grasses, while $U$. ruziziensis cover had a higher proportion of broadleaf species. However, considering dry mass, broadleaf weeds showed higher accumulations. Thus, cover crop species can affect weed community dynamics. Yet, in the second cultivation, the proportion of grass species increased in the fallow area. Conservation and conventional tillage methods are known to distinctly influence weed populations (Chauhan et al., 2012).

\section{Topdressing nitrogen fertilization}

Nitrogen topdressing rates did not differ for weed density and dry matter accumulation in both crops (Figure 2). Evaluations took place before rows were closed, that is, during weeding, as in commercial crops. By this time, $40 \%$ topdressing fertilization had been already applied. Thus, nitrogen fertilization did not favour weed growth. However, Sweeney et al. (2008) stated that nitrogen fertilization influence on weed emergence varies with species, seed source, and environmental conditions.

As weeds were at an early growth stage, environmental resources were enough to maintain their growth despite applied nitrogen. Since weed dry mass did not differ among applied $\mathrm{N}$ rates, weeds were not benefited by topdressing. Moreover, topdressing rates did not affect weed density.

\section{Treatments versus conventional tillage}

During both cultivations, no-tillage and fallow treatments showed expressive reductions in weed community when compared to conventional tillage (Table 1), regardless of nitrogen application. At the highest $\mathrm{N}$ rate, weed emergence rates in the first and second cultivations were 288.9 and 245.8 plants $\mathrm{m}^{-2}$ in conventional tillage, 4.2 and 9.7 plants $\mathrm{m}$ ${ }^{2}$ under U. ruziziensis cover, 13.9 and 38.9 plants $\mathrm{m}^{-2}$ in fallow area, and 56.9 and 20.8 plants $\mathrm{m}^{-2}$ under $C$. juncea, respectively. When comparing conventional tillage with $U$. ruziziensis cover management, weed emergence reduced 68.8 and 25.3 times and weed mass accumulation 115.9 and 131.6 times in the first and second crops, respectively, at the highest nitrogen rate. Such soil cover management may be more sustainable since it uses less labour force for weeding and soil tillage, as well as less fossil fuel use.

Our results corroborate those in the literature. Indeed, the combination of no-tillage, crop rotation, and surface residue may enhance weed control (Nichols et al., 2015). A prior summer cover crops can improve both conventional and organic vegetable production systems (Ngouajio et al., 2003).

\section{Importance value index of weed species in lettuce cultivation}

Table 2 shows the importance value indexes (IVI) of the weed species in both lettuce cultivations. Nitrogen topdressing rates had no significant effect on the dynamics of weed species. Andersson and Milberg (1998) also found that nitrogen application rate has a weak influence on the weed flora.

Conversely, the IVI of weed species was affected by soil cover management. In the first cultivation, Commelina benghalensis and Richardia brasiliensis were the only species to emerge under $U$. ruziziensis cover. This treatment was desiccated with glyphosate before lettuce planting, and both weed species are glyphosate-tolerant, even at the highest concentrations (Monquero et al., 2005). However, the other weed species were effectively controlled by $U$. ruziziensis straw layer. In $C$. juncea and fallow treatments, besides $C$. benghalensis and $R$. brasiliensis, other weed species emerged, such as Cyperus difformis, Digitaria horizontalis, Eleusine indica, Portulaca grandiflora, and P. oleracea. This greater species richness can be attributed to uneven soil cover in $C$. juncea treatment and lack thereof in the fallow area. Surface straw quantity and distribution uniformity play a major role in weed control in conservationist cultivation (Chauham et al., 2012).

In this study, the area under conventional tillage showed greater weed species richness compared to the other management evaluated. Therefore, the presence of straw and absence of disturbance in the soil help to control weeds. In this context, Plaza et al. (2015) claimed that soil tillage increases available niche opportunities for weeds.

Furthermore, Amaranthus sp. was mostly found in uncovered soils, i.e., conventional tillage and fallow areas. Since the species of this genus have very small seeds, the presence of straw can control them. Campiglia et al. (2010) 


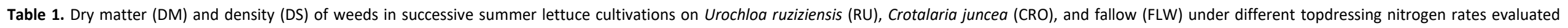
before weeding, and soil seed bank (SB) after two lettuce cultivations compared to conventional tillage (CT).

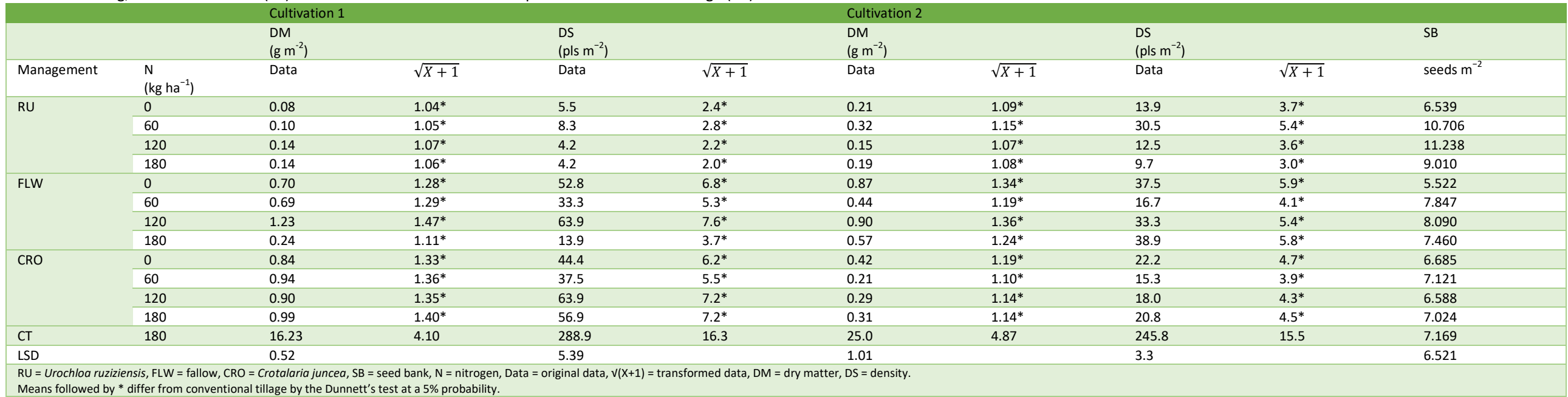


and compared to conventional tillage (CT).

\begin{tabular}{|c|c|c|c|c|c|c|c|c|c|c|c|c|c|c|}
\hline \multirow{3}{*}{ Importance value index } & \multicolumn{7}{|c|}{ Cultivation 1 summer } & \multicolumn{7}{|c|}{ Cultivation 2 summer } \\
\hline & \multicolumn{2}{|c|}{ U. ruziziensis } & \multicolumn{2}{|c|}{ C. juncea } & \multicolumn{2}{|l|}{ Fallow } & \multirow{2}{*}{$\begin{array}{l}\text { CT } \\
\text { N180 }\end{array}$} & \multicolumn{2}{|c|}{ U. ruziziensis } & \multicolumn{2}{|c|}{ C. juncea } & \multicolumn{2}{|l|}{ Fallow } & \multirow{2}{*}{$\begin{array}{l}\text { CT } \\
\text { N180 }\end{array}$} \\
\hline & No & N180 & No & N180 & No & $\mathrm{N} 180$ & & No & N180 & No & N180 & PO & P180 & \\
\hline & \multicolumn{14}{|c|}{ Importance value index } \\
\hline Alternanthera tenella & 0.0 & 0.0 & 0.0 & 11.1 & 0.0 & 0.0 & 0.0 & 0.0 & 0.0 & 0.0 & 0.0 & 0.0 & 0.0 & 4.4 \\
\hline Amaranthus sp. & 0.0 & 0.0 & 0.0 & 0.0 & 17.2 & 32.5 & 18.4 & 0.0 & 0.0 & 20.8 & 0.0 & 15.1 & 21.4 & 28.9 \\
\hline Blainvillea latifolia & 0.0 & 0.0 & 0.0 & 0.0 & 0.0 & 0.0 & 4.4 & 0.0 & 0.0 & 0.0 & 0.0 & 0.0 & 0.0 & 0.0 \\
\hline Cenchrus echinatus & 0.0 & 0.0 & 0.0 & 0.0 & 0.0 & 0.0 & 0.0 & 0.0 & 0.0 & 0.0 & 0.0 & 15.1 & 14.3 & 5.5 \\
\hline Chenopodium album & 0.0 & 0.0 & 0.0 & 0.0 & 0.0 & 0.0 & 4.4 & 0.0 & 0.0 & 0.0 & 0.0 & 15.1 & 14.3 & 4.4 \\
\hline Commelina benghalensis & 225.0 & 200.0 & 48.1 & 32.0 & 23.9 & 32.5 & 21.9 & 0.0 & 48.6 & 20.8 & 0.0 & 0.0 & 0.0 & 21.9 \\
\hline Conyza sp. & 0.0 & 0.0 & 0.0 & 0.0 & 0.0 & 0.0 & 0.0 & 65.0 & 0.0 & 33.3 & 0.0 & 0.0 & 14.3 & 0.0 \\
\hline Cyperus difformis & 0.0 & 0.0 & 123.1 & 98.2 & 109.5 & 105.0 & 58.0 & 0.0 & 77.1 & 54.2 & 91.7 & 52.4 & 107.1 & 30.0 \\
\hline Cyperus rotundus & 0.0 & 0.0 & 0.0 & 0.0 & 0.0 & 0.0 & 13.1 & 0.0 & 0.0 & 0.0 & 0.0 & 0.0 & 0.0 & 0.0 \\
\hline Digitaria horizontalis & 0.0 & 0.0 & 27.9 & 32.0 & 17.2 & 32.5 & 29.2 & 72.5 & 125.7 & 33.3 & 65.0 & 97.1 & 42.9 & 68.3 \\
\hline Digitaria insularis & 0.0 & 0.0 & 13.9 & 16.0 & 0.0 & 0.0 & 8.8 & 0.0 & 0.0 & 20.8 & 0.0 & 0.0 & 14.3 & 5.5 \\
\hline Eleusine indica & 0.0 & 0.0 & 32.7 & 51.5 & 41.1 & 0.0 & 81.1 & 32.5 & 0.0 & 41.7 & 51.7 & 74.9 & 42.9 & 52.4 \\
\hline Euphorbia heterophylla & 0.0 & 0.0 & 0.0 & 0.0 & 0.0 & 0.0 & 13.6 & 0.0 & 0.0 & 0.0 & 0.0 & 0.0 & 0.0 & 5.5 \\
\hline Gnaphalium spicatum & 0.0 & 0.0 & 0.0 & 0.0 & 0.0 & 0.0 & 0.0 & 65.0 & 48.6 & 54.2 & 0.0 & 15.1 & 0.0 & 0.0 \\
\hline Indigofera hirsuta & 0.0 & 0.0 & 0.0 & 0.0 & 11.9 & 0.0 & 0.0 & 0.0 & 0.0 & 0.0 & 0.0 & 0.0 & 0.0 & 0.0 \\
\hline Portulaca grandiflora & 0.0 & 0.0 & 13.9 & 0.0 & 0.0 & 0.0 & 0.0 & 32.5 & 0.0 & 0.0 & 0.0 & 0.0 & 14.3 & 47.9 \\
\hline Portulaca oleracea & 0.0 & 0.0 & 13.9 & 11.1 & 0.0 & 0.0 & 36.3 & 0.0 & 0.0 & 0.0 & 0.0 & 0.0 & 0.0 & 0.0 \\
\hline Richardia brasiliensis & 75.0 & 100.0 & 26.4 & 48.0 & 67.4 & 65.0 & 6.3 & 32.5 & 0.0 & 20.8 & 91.7 & 15.1 & 14.3 & 21.0 \\
\hline Sida cordifolia & 0.0 & 0.0 & 0.0 & 0.0 & 11.9 & 0.0 & 0.0 & 0.0 & 0.0 & 0.0 & 0.0 & 0.0 & 0.0 & 0.0 \\
\hline Sida glaziovii & 0.0 & 0.0 & 0.0 & 0.0 & 0.0 & 0.0 & 4.4 & 0.0 & 0.0 & 0.0 & 0.0 & 0.0 & 0.0 & 4.4 \\
\hline Synedrellopsis grisebachii & 0.0 & 0.0 & 0.0 & 0.0 & 0.0 & 32.5 & 0.0 & 0.0 & 0.0 & 0.0 & 0.0 & 0.0 & 0.0 & 0.0 \\
\hline Total & 300.0 & 300.0 & 300.0 & 300.0 & 300.0 & 300.0 & 300.0 & 300.0 & 300.0 & 300.0 & 300.0 & 300.0 & 300.0 & 300.0 \\
\hline
\end{tabular}




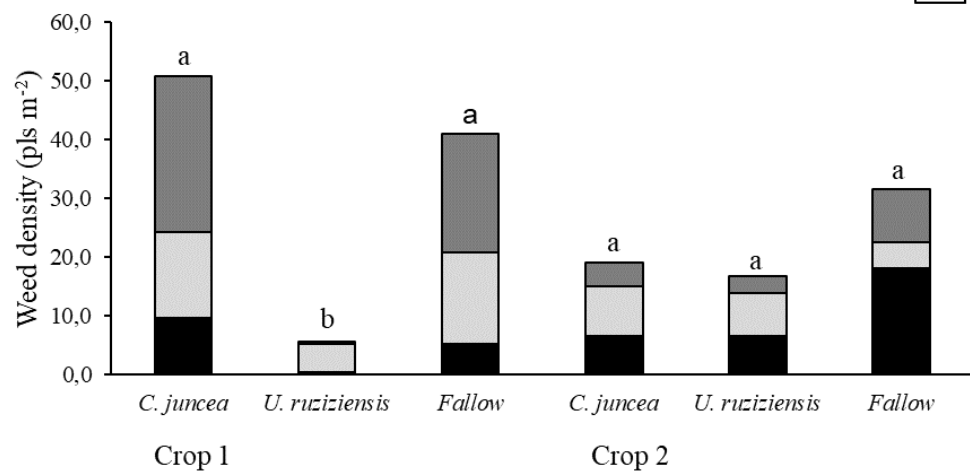

Grass aBroadleaf 口Cyperaceae

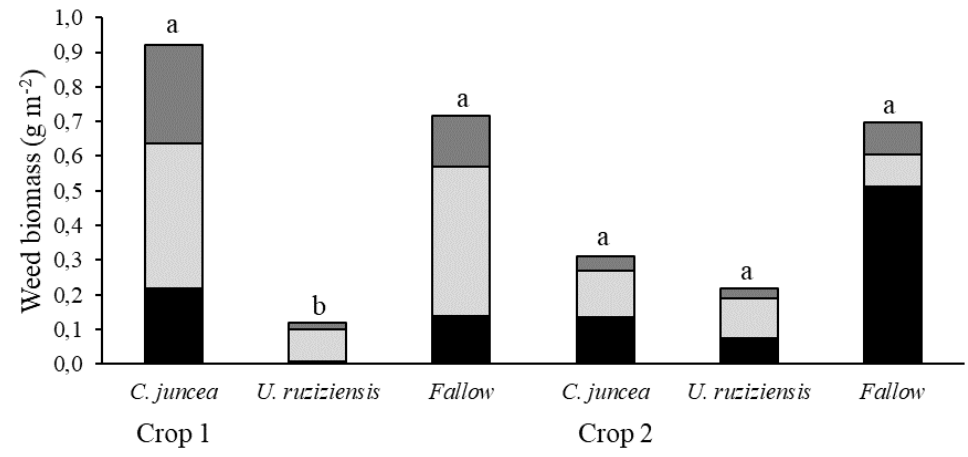

Fig 1. Density (A) and dry matter (B) of weeds in successive summer lettuce cultivations under no-tillage on Urochloa ruziziensis, Crotalaria juncea, and fallow, evaluated before weeding. The data were transformed into $\sqrt{\mathrm{x}+1.0}$ for statistical analysis - original data presented. Comparison by the Tukey's test at a $5 \%$ probability within each cultivation.

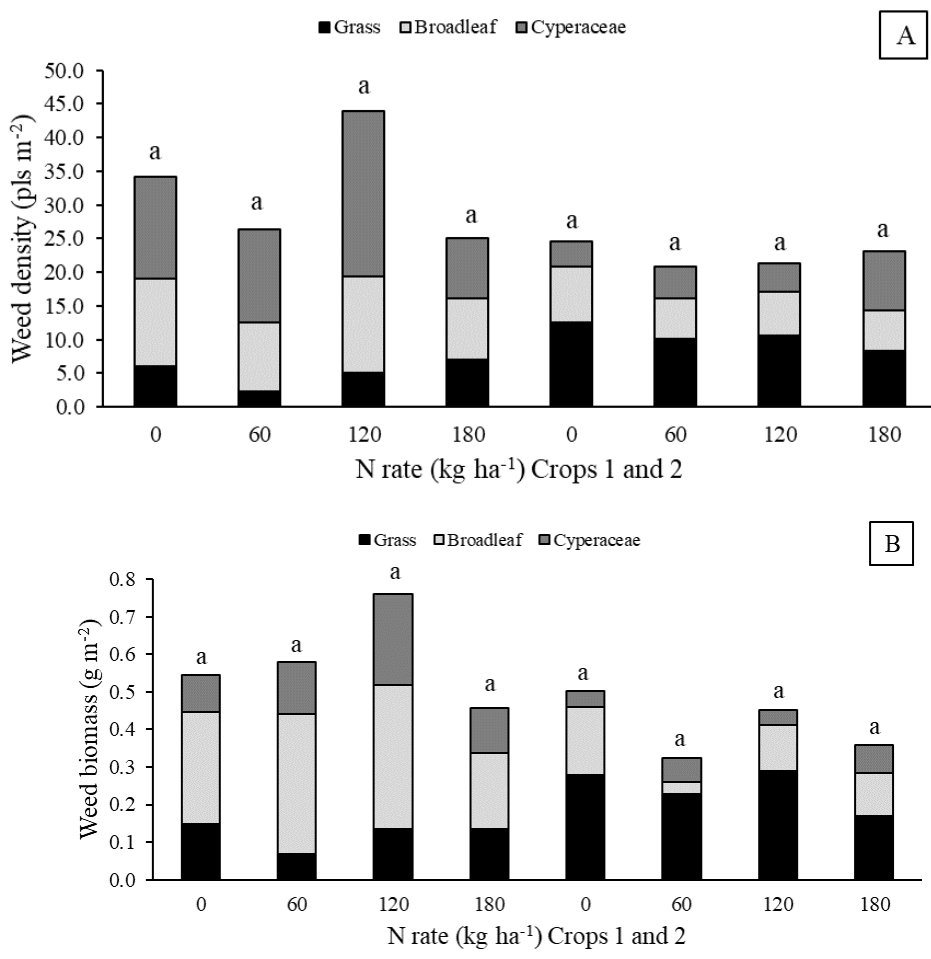

Fig 2. Density (A) and dry matter (B) of weeds in successive summer lettuce cultivations before weeding as a function of topdressing nitrogen rates in two summer lettuce cultivations. At the time of evaluation, $40 \% \mathrm{~N}$ was applied in treatments in both cultivations ( 1 and 2). The data were transformed into $\sqrt{x+1.0}$ for statistical analysis - original data presented. Comparison by the Tukey's test at a $5 \%$ probability within each cultivation. 




Fig 3. Soil weed seed banks in the 0-10 m depth layer after two successive summer lettuce cultivations under no-tillage on Urochloa ruziziensis, Crotalaria juncea, and fallow (A), and different topdressing nitrogen rates (B). Means compared by the Tukey's test at a $5 \%$ probability.

Table 3. Importance value index of non-dormant weeds in seed banks of lettuce crops on Urochloa ruziziensis, Crotalaria juncea, and fallow under different topdressing nitrogen rates after two summer cultivations compared to conventional tillage (CT).

\begin{tabular}{|c|c|c|c|c|c|c|c|}
\hline \multirow[b]{3}{*}{ Species } & \multicolumn{7}{|c|}{ Soil management } \\
\hline & \multicolumn{2}{|c|}{ U. ruziziensis } & \multicolumn{2}{|c|}{ C. juncea } & \multicolumn{2}{|l|}{ Fallow } & \multirow{2}{*}{$\begin{array}{l}\text { CT } \\
\text { N180 }\end{array}$} \\
\hline & NO & N180 & NO & N180 & NO & N180 & \\
\hline & \multicolumn{7}{|c|}{ Importance value index } \\
\hline Alternanthera tenella & 0.0 & 0.0 & 0.0 & 5.9 & 8.4 & 0.0 & 0.0 \\
\hline Amaranthus sp. & 11.1 & 8.3 & 7.0 & 5.9 & 10.2 & 25.0 & 38.5 \\
\hline Brachiaria decumbens & 0.0 & 0.0 & 0.0 & 0.0 & 0.0 & 9.3 & 0.0 \\
\hline Cenchrus echinatus & 0.0 & 0.0 & 0.0 & 7.3 & 0.0 & 0.0 & 0.0 \\
\hline Chamaesyce hirsuta & 0.0 & 0.0 & 0.0 & 5.9 & 0.0 & 0.0 & 0.0 \\
\hline Chenopodium album & 0.0 & 0.0 & 0.0 & 5.9 & 0.0 & 0.0 & 0.0 \\
\hline Commelina benghalensis & 8.1 & 15.2 & 14.0 & 0.0 & 0.0 & 0.0 & 17.7 \\
\hline Conyza sp. & 0.0 & 5.1 & 0.0 & 0.0 & 8.4 & 0.0 & 0.0 \\
\hline Cyperus difformis & 22.2 & 32.1 & 30.0 & 43.0 & 51.6 & 35.4 & 0.0 \\
\hline Desmodium tortuosum & 0.0 & 0.0 & 7.0 & 0.0 & 0.0 & 0.0 & 0.0 \\
\hline Digitaria horizontalis & 20.7 & 10.2 & 7.0 & 24.7 & 34.0 & 13.2 & 25.8 \\
\hline Eleusine indica & 0.0 & 5.1 & 7.0 & 5.9 & 0.0 & 0.0 & 11.3 \\
\hline Galinsoga parviflora & 8.1 & 0.0 & 0.0 & 0.0 & 0.0 & 0.0 & 0.0 \\
\hline Galinsoga quadriradiata & 0.0 & 0.0 & 0.0 & 0.0 & 0.0 & 15.9 & 0.0 \\
\hline Gnaphalium spicatum & 189.6 & 170.8 & 177.3 & 145.1 & 163.5 & 173.4 & 135.7 \\
\hline Indigofera hirsuta & 0.0 & 0.0 & 0.0 & 5.9 & 0.0 & 0.0 & 0.0 \\
\hline Nicandra physaloides & 0.0 & 0.0 & 0.0 & 7.3 & 0.0 & 0.0 & 0.0 \\
\hline Portulaca grandiflora & 0.0 & 10.2 & 0.0 & 0.0 & 0.0 & 0.0 & 13.1 \\
\hline Portulaca oleracea & 0.0 & 11.2 & 7.0 & 5.9 & 5.3 & 0.0 & 46.1 \\
\hline Richardia brasiliensis & 31.9 & 26.8 & 36.7 & 25.2 & 18.6 & 19.8 & 11.8 \\
\hline Sida sp. & 0.0 & 5.1 & 0.0 & 5.9 & 0.0 & 0.0 & 0.0 \\
\hline Solanum americanum & 0.0 & 0.0 & 0.0 & 0.0 & 0.0 & 8.0 & 0.0 \\
\hline Triumfetta bartramia & 8.1 & 0.0 & 7.0 & 0.0 & 0.0 & 0.0 & 0.0 \\
\hline TOTAL & 300.0 & 300.0 & 300.0 & 300.0 & 300.0 & 300.0 & 300.0 \\
\hline
\end{tabular}


found that Amaranthus retroflexus and Chenopodium album are weed species typical of conventional tillage systems. Moreover, Nichols et al. (2015) pointed out that germination and growth of annual plants with small seeds are negatively affected by low light availability, physical growth barriers, and straw allelopathic potential.

\section{Non-dormant weed seed bank in the soil}

After both successive lettuce cultivations, the weed seed bank in the $0.0-0.10 \mathrm{~m}$ soil layer of the soil managements with cover crops did not differ from the conventional tillage, regardless of nitrogen topdressing rates (Table 1 ).

The average number of seeds within this soil layer was 7,077 seeds $\mathrm{m}^{-2}$. Since the amounts of seeds that emerged over the two cultivations were high in conventional tillage and low in conservationist managements, one hypothesis for such correspondence between seed banks would be the straw effect on seed decomposition and mainly the absence of soil disturbance over two cultivations. Unlike conventional tillage, conservationist cultivations have plant beds renewed using a rotating hoe, bringing these seeds up to the soil surface.

The seed banks were not different among $U$. ruziziensis, $C$. juncea, and fallow areas and neither among nitrogen topdressing rates (Figure 3). Murphy et al. (2006) verified a reduction in seed bank under no-tillage from 41,000 to 8,000 seeds $\mathrm{m}^{-2}$ within 6 years. Unlike, Santín-Montanyá et al. (2016) found cumulative effects of soil conservation practices on seed banks, with increases in seed density and species diversity, which might have been due to specific conditions created in the soil. A little soil disturbance may have allowed maintenance of inactive seeds in the seed bank. Among other reasons, better aggregate stability and organic matter content may have helped such a situation. Despite the intensive activity in this study, the evaluation time may have been short for changes in the seed bank.

Finally, as regards the proportion of each species, the majority of non-dormant seeds that emerged were broadleaf plants, with very small proportions of grasses and cyperaceous.

\section{Importance value index (IVI) of weed species in the soil seed bank}

Table 3 shows the identified species and their importance value index (IVI) in the seed banks of all soil managements and at the extreme nitrogen rates $\left(0\right.$ and $\left.180 \mathrm{~kg} \mathrm{ha}^{-1}\right)$. In this regard, few species stood out, with Gnaphalium spicatum being the most important in all treatments, showing indexes between 135.7 to 189.6. Hirata et al. (2018) found that this species has high abundance and density in the autumnwinter, thus germinating in the same season in the next year. The species Amaranthus sp. (IVI = 38.5) and Portulaca oleracea (IVI $=46.1$ ) stood out in the conventional treatment. The species $R$. brasiliensis and $C$. difformis were also important in $U$. ruziziensis and $C$. juncea treatments, while the species $C$. difformis stood out in the fallow. According to Derakhshan and Gherekhloo (2013), seeds of $C$. difformis sown on the soil surface reached the highest seedling emergence percentage, and no seedlings emerged from seeds buried to a depth of $0.01 \mathrm{~m}$. This species is usually adapted to high moisture soils, and no seeds were found in the seed bank of the conventional tillage treatment. Soil disturbance in conventional tillage may have affected negatively the weed seeds compared to no-tillage areas, where moisture is well preserved.
The dynamics of weed species in the seed bank was not affected by nitrogen fertilization. For Davis (2007), soil nitrogen effect on weed seed mortality is species-specific, wherein some species are affected by nitrogen in soil microbiota, which, in turn, act as seed predators, whereas other species are affected during germination.

Other factors such as soil temperature, $\mathrm{pH}$, electrical conductivity, structure, and organic matter content, as well as liming, preceding crops, herbicide use, cropping time, and manure amounts, can be the main responsible for week community changes and formation of different associations, as stated by lqbal et al. (2018).

\section{Materials and methods}

\section{Experimental site}

The experiment was installed at the Agency for Agribusiness Technology of São Paulo (APTA), in the city of Presidente Prudente, São Paulo State, Brazil $\left(22^{\circ} 07^{\prime} 21^{\prime \prime}\right.$ S, $51^{\circ} 23^{\prime} 17 S^{\prime \prime}$ W, and $460-\mathrm{m}$ altitude). According to Köppen's classification, the local climate is classified as $A w$, which stands for a rainy tropical climate with dry winters (CEPAGRI, 2015).

\section{Physical and chemical description of the soil}

The experiment was carried out on loamy sandy soil, which is classified as arenic dystrophic Red Yellow Argissolo by the Brazilian Soil Classification System. The soil is composed of $4.7 \%$ clay, $12.1 \%$ silt, and $82.3 \%$ total sand, with a predominance of fine sand. Soil chemical characteristics are as follows: $5.4 \mathrm{pH}$ in $\mathrm{CaCl}_{2}, 17 \mathrm{~g} \mathrm{dm}^{-3}$ organic matter, $73 \%$ base saturation, $63.0 \mathrm{mg} \mathrm{dm}^{-3} \mathrm{P}, 1.8 \mathrm{mg} \mathrm{dm}^{-3} \mathrm{Zn}, 22.0 \mathrm{mg}$ $\mathrm{dm}^{-3} \mathrm{Fe}, 26.3 \mathrm{mg} \mathrm{dm}^{-3} \mathrm{Mn}, 1.3 \mathrm{mg} \mathrm{dm}^{-3} \mathrm{Cu}, 0.21 \mathrm{mg} \mathrm{dm}^{-3} \mathrm{~B}$, $5.2 \mathrm{mmol}_{\mathrm{c}} \mathrm{dm}^{-3} \mathrm{~K}, 21.0 \mathrm{mmol}_{\mathrm{c}} \mathrm{dm}^{-3} \mathrm{Ca}, 7.0 \mathrm{mmol}_{\mathrm{c}} \mathrm{dm}^{-3} \mathrm{Mg}$, and $12.0 \mathrm{mmol}_{\mathrm{c}} \mathrm{dm}^{-3} \mathrm{H}+\mathrm{Al}$. The chemical analysis was performed according to the method proposed by Raij et al. (2001), with soil correction using dolomitic limestone to increase base saturation to $80 \%$.

\section{Experimental design}

The experimental design was carried out in random blocks with four replicates. Treatments were arranged in a $(4 \times 3)+1$ factorial scheme, with the additional control. The first factor consisted of four topdressing nitrogen rates $(0,60,120$, and $180 \mathrm{~kg} \mathrm{ha}^{-1}$ ) applied to lettuce through drip system fertigation, using urea as nitrogen source. The second factor comprised three soil cover management systems: fallow (soil tilled and hoed for 50 days), and two no-tillage systems, one using Crotalaria juncea cover and the other Urochloa ruziziensis cover.

The additional control consisted of conventional tillage, representing the traditionally used system. Therein, organic fertilization was performed by applying poultry manure superficially in both lettuce cultivations $\left(\mathrm{N}=18 \mathrm{~g} \mathrm{~kg}^{-1}, \mathrm{P}=\right.$ $16.6 \mathrm{~g} \mathrm{~kg}^{-1}, \mathrm{~K}=23.9 \mathrm{~g} \mathrm{~kg}^{-1}, \mathrm{Ca}=92.2 \mathrm{~g} \mathrm{~kg}^{-1}, \mathrm{Mg}=6.3 \mathrm{~g} \mathrm{~kg}^{-1}$, and $S=4.0 \mathrm{~g} \mathrm{~kg}^{-1}$ ) at a rate of $200 \mathrm{~g} \mathrm{~m}^{-2}$ (9.6\% moisture) to replace cover crops. A micro-sprinkler irrigation system was used in this treatment, and a nitrogen topdressing rate of $180 \mathrm{~kg} \mathrm{ha}^{-1}$ was applied manually. In this treatment, the planting bed was first built when lettuce seedlings were planted, and then rebuilt in the second cultivation, incorporating thermophosphate fertilizer (total $\mathrm{P}_{2} \mathrm{O}_{5}=16 \%$, total $\mathrm{Ca}=16 \%, \mathrm{Mg}=6.5 \%, \mathrm{~B}=0.1 \%, \mathrm{Cu}=0.05 \%, \mathrm{Mn}=0.3 \%$, $\mathrm{Zn}=0.55 \%, \mathrm{~S}=6.0 \%$, and $\mathrm{Si}=9.0 \%$ ) in both cultivations at $100 \mathrm{~g} \mathrm{~m}^{-2}$. 
All treatments were fertilized at planting with $50 \mathrm{~kg} \mathrm{~K}_{2} \mathrm{O} \mathrm{ha}{ }^{-1}$ and $20 \mathrm{~kg} \mathrm{~N} \mathrm{ha}^{-1}$, according to Trani et al. (2018).

\section{Cover crop implantation}

Planting beds were built using a bed mulcher, and plots were $4.2 \mathrm{~m}$ long and $1.2 \mathrm{~m}$ wide. Thermophosphate $\left(100 \mathrm{~g} \mathrm{~m}^{-2}\right)$ was incorporated into the planting beds before sowing $C$. juncea and $U$. ruziziensis. Sowing was performed along four rows spaced $0.30 \mathrm{~m}$ apart and longitudinally to the beds, using $40 \mathrm{~kg} \mathrm{ha}^{-1} \mathrm{C}$. juncea seeds (60\% germination) and $12 \mathrm{~kg}$ $\mathrm{ha}^{-1} U$. ruziziensis seeds (65\% germination). Cover crops were desiccated using glyphosate at $2.5 \mathrm{~L}$ commercial product ha ${ }^{-1}$ ( 480 g a.i. $\mathrm{L}^{-1}$ ) on December 28, 2019 (50 days after emergence).

\section{Lettuce planting}

Crispy-leaf lettuce plants of the cultivar Vanda were used. The first cultivation was started 14 days after desiccation and harvested 37 days after planting. After harvesting, the area was newly desiccated with ammonium glufosinate at $2.0 \mathrm{~L}$ commercial product ha ${ }^{-1}\left(200 \mathrm{~g}\right.$ a.i. $\left.\mathrm{L}^{-1}\right)$. The second planting was then carried out 7 days after the previous crop harvest and harvested 38 days after its planting.

\section{Measured traits}

\section{Cover crop}

Cover crop straws were sampled at lettuce planting time and after both lettuce cultivations. Sampling was carried out using two $0.30 \times 0.30 \mathrm{~m}$ frames placed on each plot. Straw amounts within frames were washed to remove adhered soil and dried in a forced-air circulation oven at $65^{\circ} \mathrm{C}$.

\section{Weed community}

Weed community was evaluated 15 and 17 days after the first and second cultivations, respectively, before weeding and crop row full covering. Weed sampling was done by randomly casting two $0.30 \times 0.30 \mathrm{~m}$ frames along crop interrow. The weeds within the frames were identified, separated into broadleaf species, grasses, and nutgrasses (Cyperus), and measured for dry matter after drying a forced-air circulation oven at $65^{\circ} \mathrm{C}$.

\section{Weed seed banks}

Soil weed seed banks were evaluated at the end of the second cultivation. Three soil samples were collected per plot within the $0.0-0.10 \mathrm{~m}$ depth layer using a cylinder. Cylinder dimensions allowed to calculate the volume of soil collected from each plot, and the number of weeds per square meter of soil collected in the treatment.

Soil samples were placed onto plastic trays and kept wet in a greenhouse for weed emergence evaluation. After each weed emergence flow, the plants were removed and the soil disturbed to stimulate further flows. This procedure was performed for about 7 months. Afterwards, the water supply was suppressed to stimulate new emergence flows.

\section{Phytosociological parameters}

Phytosociological parameters assessed were frequency, density, and abundance of weed species, using data from evaluations. The results allowed calculating relative frequency, relative density, and relative abundance to then determine the importance value index of each species. These parameters were calculated using the formulas proposed by Mueller-Dombois and Ellenberg (1974).

\section{Statistical analysis}

The results were subjected to analysis of variance, and means compared by the Tukey's test at $5 \%$ probability. The Dunnett's test at $5 \%$ probability was used to compare treatments and additional control.

\section{Conclusions}

Lettuce cultivation on Urochloa ruziziensis cover improves weed control efficiency. Due to high soil disturbance, conventional tillage is more favourable to weed infestation than cultivations in fallow, U. ruziziensis-covered, and $C$. juncea-covered areas. Nitrogen topdressing does not interfere with weed management in lettuce crops. Tillage systems and nitrogen fertilization do not affect weed seed banks. The tillage system alters weed species dynamics in lettuce crops.

\section{Acknowledgements}

The authors would like to thank the Foundation for Research Support of the State of São Paulo (FAPESP) for the financial support. Number of foundation Process: (FAPESP 2018/21564-3)

\section{References}

Abouziena HF, El-Karmany MF, Singh M, Sharma SD (2007) Effect of nitrogen rates and weed control treatments on maize yield and associated weeds in sandy soils. Weed Technol. 21: 1049e1053.

Andersson TN, Milberg P (1998) Weed flora and the relative importance of site, crop, crop rotation, and nitrogen. Weed Sci. 46: 30-38.

Andreasen C, Litz AS, Streibig JC (2006) Growth response of six weed species and spring barley (Hordeum vulgare) to increasing levels of nitrogen and phosphorus. Weed Res. 46: 503-512.

Barker DC, Knezevic SZ, Martin AR, Walters DT, Lindquist JL (2006) Effect of nitrogen addition on the comparative productivity of corn and velvetleaf (Abutilon theophrasti). Weed Sci. 54: 354-363.

Blubaugh CK, Kaplan I (2015) Tillage compromises weed seed predator activity across developmental stages. Biol Control. 81: 76-82.

Buhler DD (1997). Effects of tillage and light environment on emergence of 13 annual weeds. Weed Technol. 11: 496501.

Campiglia E, Mancinelli R, Radicetti E, Caporali F (2010) Effect of cover crops and mulches on weed control and nitrogen fertilization in tomato (Lycopersicon esculentum Mill.). Crop Prot. 29: 354-363.

CEPAGRI. 2015, 30 de abril. Meteorologia Unicamp. Disponível em: <http://www.cepagri.unicamp.br/outrasinformacoes/clima-dos-municipios-paulistas.html>

Chauhan BS, Singh RG, Mahajan G (2012) Ecology and management of weeds under conservation agriculture: $A$ review. Crop Prot. 38: 57-65.

Creamer NG, Baldwin KR (2000) An evaluation of summer cover crops for use in vegetable production systems in North Carolina. Hortscience. 35: 600-603.

Davis AS (2007) Nitrogen fertilizer and crop residue effects on seed mortality and germination of eight annual weed species. Weed Sci. 55: 123- 128. 
Derakhshan A, Gherekhloo J (2013) Factors affecting Cyperus difformis seed germination and seedling emergence. Planta Daninha. 31: 823-832.

Evans S, Knezevic SZ, Lindquist J, Shapiro C (2003) Influence of nitrogen and duration of weed interference on corn growth and development. Weed Sci. 51: 546-556.

Hirata ACS, Duarte AP, Duarte RCRM (2018) Weeds in second corn crops in the period of transgenic soybean implantation in the Middle Paranapanema region. Planta Daninha. 36: [e018176809.

Hirata ACS, Hirata EK, Guimarães EC, Rós AB, Monquero PA. (2014). Plantio direto de alface americana sobre plantas de cobertura dessecadas ou roçadas. Bragantia. 73: 178-183.

Iqbal, M, Khan SM, Khan MA, Ahmad Z, Ahmad H (2018) A novel approach to phytosociological classification of weeds flora of an agro-ecological system through cluster, twoway cluster and indicator species analyses. Ecol Indic. 84: 590-606.

Isik D, Kaya E, Ngouajio M, Menna H (2009) Summer cover crops for weed management and yield improvement in organic lettuce (Lactuca sativa) production. Phytoparasitica. 37: 193-203.

Jensen PK (1995) Effect of light environment during soil disturbance on germination and emergence pattern of weeds. Ann Appl Biol. 127: 561-571.

Jørnsgård B, Rasmussen K, Hill J, Christiansen JL (1996) Influence of nitrogen on competition between cereals and their natural weed populations. Weed Res. 36: 461-470.

Kruse R, Nair A (2016) Summer cover crops and lettuce planting time influence weed population, soil nitrogen concentration, and lettuce yields. HortTecnology. 26: 409416.

Lundy $\mathrm{ME}$, Pittelkow CM, Linquist BA, Liang $X$, Groenigen KJV, Lee J, Six J, Venterea RT (2015) Nitrogen fertilization reduces yield declines following no-till adoption. Field Crop Res. 183: 204-210.

Maclaren C, Storkey J, Menegat A, Metcalfe H, DehnenSchmutz K (2020) An ecological future for weed science to sustain crop production and the environment. A review. Agron Sustain Dev. 40: 1-29.

Mennan H, Jabran K, Zandstra BH, Pala F (2020) Nonchemical weed management in vegetables by using cover crops: a review. Agronomy. 10: 257.

Nikolić N, Squartini A, Concheri G, Stevanato P, Zanin G, Masin R (2020) Weed seed decay in no-till field and planted riparian buffer zone. Plants. 9: 293.

Monquero PA, Cury JC, Chistoffoleti PJ (2005) Controle pelo glyphosate e caracterização geral da superfície foliar de Commelina benghalensis, Ipomoea hederifolia, Richardia brasiliensis e Galinsoga parviflora. Planta Daninha. 23: 123-132.
Mueller-Dombois D, Ellenberg HA (1974) Aims methods of vegetations ecology. New York: John Wiley, 547p.

Murphy SD, Clements DR, Belaoussoff S, Kevan PG, Swanton CJ (2006) Promotion of weed species diversity and reduction of weed seedbanks with conservation tillage and crop rotation. Weed Sci. 54: 69-77.

Nichols V, Verhulst N, Cox R, Govaerts B (2015) Weed dynamics and conservation agriculture principles: $A$ review. Field Crop Res. 183: 56-68.

Pittelkow CM, Liang X, Linquist BA, van Groenigen KJ, Lee J, Lundy ME, van Gestel N, Six J, Venterea RT, van Kessel C (2015) Productivity limits and potentials of the principles of conservation agriculture: Nature. 517: 365-368.

Plaza EA, Navarrete L, González-Andújar JL (2015) Intensity of soil disturbance shapes response trait diversity of weed communities: The long-term effects of different tillage systems. Agr Ecosyst Environ. 207: 101-108.

Ngouajio M, Mcgiffen ME, Hutchinson CM (2003) Effect of cover crop and management system on weed populations in lettuce. Crop Prot. 22: 57-64.

Raik B, Andrade JC, Cantarella H, Quaggio JA (2001) Análise química para avaliação da fertilidade de solos tropicais Campinas: IAC. 284p.

Santín-Montanyá MI, Martín-Lammerding D, Zambrana E, Tenorio JL (2016) Management of weed emergence and weed seed bank in response to different tillage, cropping systems and selected soil properties. Soil Till Res. 161: 3846.

Shem-Tov S, Fennimore SA, Lanini WT (2006) Weed management in lettuce (Lactuca sativa) with preplant irrigation. Weed Technol. 20: 1058-1065.

Silva PCG, Foloni, JSS, Fabris LB, Tiritan CS (2009) Fitomassa e relação $\mathrm{C} / \mathrm{N}$ em consórcios de sorgo e milho com espécies de cobertura. Pesqui Agropecu Bras. 44: 1504-1512.

Trani PE, Raij BV, Cantarella H, Figueiredo GJB (2018) Hortaliças: recomendações de calagem e adubação para o estado de São Paulo. Campinas: Cati. 88p. (Boletim Técnico, 251)

Wang L, Liu Q, Dong X, Liu Y, Lu J (2019) Herbicide and nitrogen rate effects on weed suppression, $\mathrm{N}$ uptake, use efficiency and yield in winter oilseed rape (Brassica napus L.). Glob Ecol Conserv. 17: e00529.

Sweeney AE, Renner KA, Laboski C, Davis A (2008) Effect of fertilizer nitrogen on weed emergence and growth. Weed Sci. 56: 714-721. 